\title{
The responsibility principle. Contradictions of priority-setting in Swedish healthcare
}

Werner Schirmer and Dimitris Michailakis

\section{Linköping University Post Print}

N.B.: When citing this work, cite the original article.

Original Publication:

Werner Schirmer and Dimitris Michailakis, The responsibility principle. Contradictions of priority-setting in Swedish healthcare, 2011, Acta Sociologica, (54), 3, 267-282.

http://dx.doi.org/10.1177/0001699311412624

Copyright: SAGE Publications (UK and US)

http://www.uk.sagepub.com/

Postprint available at: Linköping University Electronic Press

http://urn.kb.se/resolve?urn=urn:nbn:se:liu:diva-70743 


\title{
The responsibility principle. Contradictions of priority- setting in Swedish healthcare
}

(latest and slightly edited version published in Acta Sociologica 54(3) 267-282)

\author{
Werner Schirmer \\ then: Department of Sociology, Uppsala University, Sweden \\ now: Department of Social and Welfare Studies, University of Linköping, Sweden
}

Dimitris Michailakis

Department of Social and Welfare Studies, University of Linköping, Sweden

\begin{abstract}
In Sweden medical priority-setting have been discussed heatedly since the 1990s. While criteria such as medical need, solidarity and cost-effectiveness were established early, they failed to give clear directives for decision-makers how to prioritize. The notion of individual responsibility for one's health was suggested as solution out of the impasse. According to the responsibility principle, those who fail to live up to the expectations of a healthy lifestyle can legitimately be downprioritized. Although the principle gains increasing support, its effectiveness is hampered by structural problems.

We analyzed official reports and pertinent forums of the Swedish debate on priority-setting from 1990-2009. The article examines the responsibility principle with a Luhmannian framework. Unlike common criticisms which emphasize difficulties of assessing whether individuals actually can be held accountable for their lifestyle, we found that the responsibility principle fails in its current form because it unifies two incompatible logics that are deeply rooted in the functionally differentiated structure of society: that of medical reasoning (connecting health condition with lifestyle) and political expediency (attributing responsibility). We conclude that future policy-making cannot tacitly pass over this conflict but has to acknowledge its presence and constructively utilize its potential.
\end{abstract}

\section{Keywords}

Healthcare, lifestyle, Luhmann, responsibility, systems theory, welfare state 


\section{Introduction}

\section{Background}

For many decades, the Nordic countries have received much praise and admiration for their extensive welfare states of the social democratic type (Esping-Andersen, 1990). The Swedish motto is 'alla ska med' (everyone onboard), meaning that no one should be excluded from social benefits. This ambitious political self-description has fostered enormous expectations among Swedish citizens that are difficult to accommodate in the light of several waves of economic decline since the late 1980s.

In healthcare, this situation has become particularly salient. Technological advancements in medicine make costs for public health grow, while demographic changes and decreasing tax volume challenge the ability to finance them. When the budget gap did not allow expensive treatments for everyone anymore, the Swedish state began to see medical priority-setting as inevitable (Calltorp, 1989, 1992, 1999; Riksrevisionen, 2004: 13; SOU, 1993: 28-29; 1997; 2008).

Like the Anglo-Saxon countries (Callahan, 1987; Ginzberg, 1990; Ham, 1997; Daniels and Sabin, 2002), Sweden is rather inexperienced in medical priority setting. The first important public investigation into the issue was commissioned by the government as late as 1992 and delivered its final report in 1995, when it proposed an 'ethical platform' containing a hierarchy of three principles for priority-setting (the 'human dignity principle', the 'principle of need and solidarity' and the 'principle of cost-effectiveness'). Two years later, the parliament passed the ethical platform in a government bill (The Swedish Government, 1997) as a guideline for decisionmaking. However, several evaluations showed that the platform failed to fulfil its official goals; namely, it could neither provide guidance to physicians nor contribute 
to saving significant amounts of money (Gunnarsdotter, 2007: 3174). Consequently, major revisions of the platform were demanded. Assigned with the task to find better guidelines, the National Centre for Priority Setting (Prioriteringscentrum) proposed - among other things - the implementation of the notion of 'responsibility for one's health' as a principle for prioritization. According to this principle, people can be given lower priority if their unhealthy lifestyle is a cause of their disease, derogates their health conditions or endangers the success of medical treatment.

There are many critical academic accounts of responsibility in the context of health (Beck-Gernsheim, 2000; Light and Hughes, 2001; Jolanki, 2008; Wikler, 2002). Some have highlighted the moral dilemmas doctors find themselves in when setting priorities between patients and treatments (Michaelis, 2002; Ham and Glen, 2003). Difficulties are expected when physicians have to judge whether patients' diseases are self-inflicted (Minkler, 1999). Critical studies view responsibility for one's health as an indicator of neo-liberal deregulation politics (Donahue and McGuire, 1995; Martin et al, 2002; Turner, 2004).

Accordingly, the notion of responsibility for one's health may be well in line with the lean, individualistic and liberal welfare-tradition of the UK or the US, but it contradicts more or less openly the self-description of a collectivist, redistributive and caring welfare state like the Swedish one. In the first run of 1995, the responsibility principle was rejected. From 2007 on, however, it has been promoted as a significant improvement to the impasse of the previous ethical platform. 


\section{Research problem}

Many reasons for the failure of the previous ethical platform have been proposed in official evaluations; e.g. ambiguous principles, the hierarchical ordering of principles, practitioners' lack of awareness and willingness to apply the principles, etc. (Prioriteringscentrum, 2007). While acknowledging that these factors did their part, we suggest that to a substantial extent an underlying societal-structural problem accounts for the failure of the platform. We will also argue that the responsibility principle rests on the same societal premises that account for the structural problem. The first task of this article is, therefore, to disclose that problem by means of a sociological analysis of the pre-existing prioritization criteria; the second task is to assess the responsibility principle within this context. Because rule catalogues and criteria are supposed to apply in a variety of different concrete situations, they are necessarily formulated on a very abstract level. Accordingly, we focus not on the dilemmas of concrete decision-making processes and problems of practical implementation different actors face, but on the debate where criteria are communicated, suggested and contested.

We examined a considerable number of texts selected mainly from official documents and pertinent forums of the Swedish debate on priority-setting since the early 1990s. The analysis is guided by the systems-theoretical framework as developed by German sociologist Niklas Luhmann (Luhmann, 1989, 1997; Hagen, 2000; Stichweh, 2000), which offers a powerful conceptual apparatus at different levels of abstraction (observation theory, social theory of communication, theory of society) that combines systematic observations of communication with sociological explanations. The Luhmannian approach allows us to maintain a sociological 
distance to our research object by distinguishing between the application of moral standards and the observation of moral standards. When analyzing the Swedish prioritization debate, we observe how debaters apply moral standards when referring to prioritization.

The article is structured as follows: In section 2 we show that modern values (human dignity and equality) set the frame of ethicality for any prioritization criteria, whereas ascriptive social attributes (e.g. sex, race, status) have no footing. Explicitly advocating modern morals, the Swedish debate has anchored a principle of human dignity to preside over any catalogue of criteria. We argue in section 3 that priorities built on this principle are paradoxical since they imply ranking of people with equal worth. In order to make priority rules operative, decision-makers have to find reasonable exemptions from the human dignity principle. Our empirical study is elaborated in section 4 and searches the Swedish prioritization debate for such criteria. We examined the data-material with help of a systems-theoretical textualanalysis method and discovered contradictions between all suggested criteria, which run along the difference between welfare-political and medical observation modes. Following Luhmann's approach, we interpret this gap as an unavoidable consequence of society's structure of functional differentiation. Section 5 takes this societal-structural background as a starting point and scrutinizes the responsibility principle's capacity for solving the operational problem. When re-examining the data with special focus on the debate about responsibility and its structural premises, we find that the concepts 'responsibility for one's health' and '(un)healthy lifestyle' are intermingled. Luhmann's theory of society helps us hold apart lifestyle as a strictly medical concept from responsibility - a strictly political concept. In the end, the 
responsibility principle can be disclosed as a political attempt to utilize medical reasoning for its own purposes, but this attempt fails because politics cannot intervene into medical practice as such.

\section{Ethicality}

Let us begin with a thought experiment. Imagine yourself in the role of a surgeon in an emergency room. Two seriously injured patients are admitted at the same time. Both are in urgent need of treatment but there is capacity for medicating only one at a time. The patient treated first will survive while the other most likely will die. One of them is a relative of yours whereas you have no special relationship to the other. Which one would you treat first? Would it not feel natural to prioritize your relative? Alternatively, imagine that one of the patients is your fellow countryman while the other comes from a country at war with yours? Would it not feel evident to give priority to your countryman $?^{1}$

Although plausible at first sight, these reasons do not seem appropriate, and careful decision-makers would not follow them. If prioritization is necessary due to scarcity of resources people need to be ranked in a way that Turner (2004: 144) calls a 'moral queue', that is, a queue built upon socially approved moral values rather than a first-in-first-out routine. In pre-modern societies, it was self-evident that people be ranked according to ascriptive social attributes (such as kinship, friendship, ethnic origin as well as sex and social status). Differential treatment of people along ascriptive attributes only mirrored the order of things (Luhmann, 1997: 678-706) and was, accordingly, backed up by the dominating moral principles. In modern society, moral queues cannot be built on ascriptive criteria. They have to be 
based on values as developed in the aftermath of European enlightenment, especially equality and human dignity. These values are seen as valid from birth for every person and are typically carved in stone in many modern constitutions and charters. In the Basic Principles of the Swedish Constitution it is formulated as follows ${ }^{2}$ :

The public institutions shall promote the opportunity for all to attain participation and equality in society. The public institutions shall combat discrimination of persons on grounds of gender, colour, national or ethnic origin, linguistic or religious affiliation, functional disability, sexual orientation, age or other circumstances affecting the private person. (The Swedish Parliament)

The values stressed in such significant legal-political documents are difficult to combine with the usage of ascriptive social attributes as criteria in priority-setting. Inequality based on ascriptive criteria gives rise to indignation and protest. Such events are regularly reported in the mass media, as the following two examples illustrate.

The number of deaths due to [curable] diseases is three times higher for low-skilled people than for high-skilled. Residents born outside of Sweden more often consider themselves to be met with disrespect when they demand medical care. That is how unfair the Swedish healthcare is. (Aftonbladet, 2009)

The healthcare system fails in its encounter with women. [...] That is totally unacceptable, and all of us working in healthcare are responsible for changing it. It is important that people who need care are encountered well, from a humane as well as a medical perspective. It applies for women as well as men. (Brodén, 2008)

Cases like these - as normal they may have been in the past - are nowadays mostly considered as nepotism, sexism or chauvinism, and this is possible exactly because modern moral standards are used for judgment. If it was for effectiveness only, one or a combination of some ascriptive social attributes would be a quite suitable ordering principle for prioritization queues, like in the thought experiment, but modern society considers them as unethical. Acceptable candidates for prioritization criteria must comply with modern morals. Drawing on Spencer Brown's concept of 
'form' (1994), figure 1 visualizes the distinction between priority criteria that accommodate ethical standards and those making use of ascriptive criteria (vertical line); the term that divides both sides is ethicality. Consequently, ethicality provides the most basic frame for sorting prioritization criteria: unethical criteria are sorted out. The horizontal line symbolizes that only the ethically accepted side is marked.

Figure 1: Ethicality

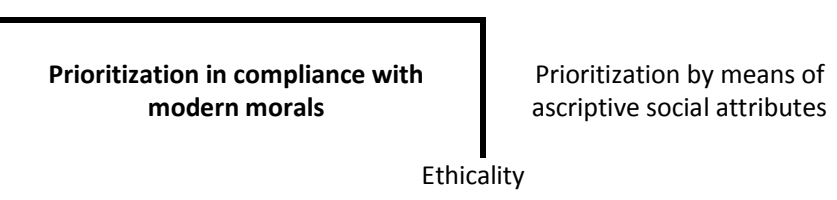

\section{Prioritization paradox}

When priority-setting finally became an issue in Swedish medico-political debates in the mid 1990s, an 'Ethical Platform' was adopted with a focus on excluding ascriptive categories. The platform positioned the 'human dignity principle' (HDP) as the first, most important and overarching principle for priority-setting in Sweden, according to which 'all people are of equal value and have the same rights regardless of personal characteristics and functions in society' (The Swedish Government, 1997). Since then, it has been unchallenged (SOU, 2001: 33) and re-iterated in every official report and public investigation on priority-setting to the present day.

The Ethical Platform considers the HDP as unconditional and therefore superior to other principles; the latter are only subsidiary. However, this approach is based on a logical paradox: unconditional equal value of human beings contradicts the very idea of prioritization. Setting priorities means selecting someone instead of someone else, i.e. it means (at least partial) exclusion. The HDP does not allow 
excluding but is rather an appeal to include people. Put differently, the idea of equal value of everyone due to their human nature (born as equals) undermines an effective ranking of candidates in queue for medical treatment.

The HDP subsists by consensus of all involved debaters and decision-makers and, thus, it has to be taken seriously. Yet, prioritization criteria have to derive their legitimacy from within the framework of the human dignity principle, while factually running counter to the idea of equal human value. Hence, a practical ranking of equals requires a suspension of the human dignity principle that is justifiable on grounds of other values. These have to compete with human dignity - not in terms of ethicality but of practicality. What we, then, are looking for are reasonable exemptions from the human dignity principle. Figure 2 symbolizes this new distinction (HDP/reasonable exemptions from HDP) within the frame of the previous distinction from figure 1. Both HDP and reasonable exemptions from it are deemed ethical (in contrast to ascriptive criteria), but only the exemptions are practical.

Figure 2: Practicality

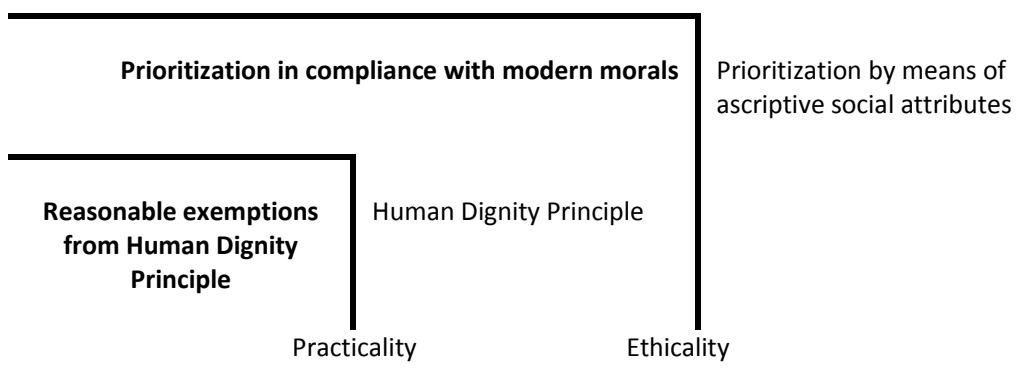




\section{Finding reasonable exemptions from the human dignity principle}

\subsection{Method}

With this pre-understanding we start our analysis of ethical and practicable criteria for priority-setting for the Swedish healthcare system. The aim of this section is to examine the underlying assumptions of the proposed prioritization criteria and social-structural reasons for their failure. In this subsection, we will present our data material and the sampling procedure (I). After that we unfold the epistemological assumptions of the analysis-method (II) and its procedure (III).

I) Data material. Publicly available documents of the public debate provide very useful empirical data material for our purpose. It is exactly here where potential principles for legislation are communicated, discussed and contested. Aiming for a well-grounded grip on the Swedish debates on prioritization, our sample comprises the Journal of The Swedish Medical Association 'Läkartidningen' (LT), the relevant government official reports (SOU) on priority-setting, publications from 'Prioriteringscentrum', reports from 'The National Board of Health', and, finally, articles from the daily press. Texts eligible for the sample had to be published between 1990 and 2009, and were identified by means of the key word 'prioritering' (prioritization). 181 articles from LT were selected by searching for articles whose titles contained the word 'priori*'. Besides that we consulted: (a) 50 articles from the main daily newspapers, approx. 60 pages; (b) 8 reports from the public authorities 'The National Board of Health', 'The Swedish National Audit Office' and 'Swedish National Institute of Public Health', approx. 910 pages; (c) 6 SOU reports, 'Government Bills' and 'Reports from the Standing Committee of Health', approx. 840 pages; and (d) 6 reports from Prioriteringscentrum, approx. 526 pages. 
Altogether, our raw data material consists of 70 different texts with a total length of approximately 2400 A 4 pages. After reductions (see subsection III), the analyzed material comprised approximately 200 pages.

II) Epistemological assumptions of the method: We do not intend to analyze which prioritization criteria are implemented in practice or how (in)efficient they have been as guidelines for decision-making. Instead we examine on a more basic level the communicative frame within which criteria are proposed, derive their meaning and have to compete for reasonability. In the analyzed texts, the debate touches on several levels of prioritization, but the ethical platform to which most of the criteria and principles as well as accompanying reports refer to is prioritization on the clinical level.

Common to all these texts in our material is that they produce specific observerdependent (and potentially mutually mismatching) descriptions of the prioritization issue. Any utterance, statement and argument pro or against is generated by means of particular binary distinctions (Vanderstraeten, 2001; Luhmann, 2006; Seidl and Becker, 2006), for example ethical/unethical or reasonable/unreasonable. As researchers, our task is to analyse these (relevant) distinctions in order to gain access to the socio-structural premises underlying the specific descriptions in the texts. Sometimes these distinctions are overt and explicit; sometimes they are hidden or simply presupposed without spokesmen necessarily being aware of them. We need a method suitable to disclose how meaning in texts is formed when specific distinctions are linked to each other. Consequently, this method must be developed explicitly on the epistemological assumptions of the Luhmannian systems-theoretical approach we employ in this study. The method we choose is called 'Radical 
Hermeneutics (RH)' developed by Jens Rasmussen (2002, 2004: 322-348) and fulfils this requirement.

We will now briefly describe the basic assumptions of $\mathrm{RH}$. The method belongs to the wider family of hermeneutics and builds on core concepts such as 'meaning', 'understanding' and 'interpretation'. Accordingly, the method aims at understanding texts. In contrast to traditional versions of hermeneutics (Schleiermacher, Gadamer, Ricoeur), RH rejects the assumption that meaning is discovered through a reciprocal interchange between text and interpreter (hermeneutic circle). Building on Luhmann's epistemological 'operative constructivism', Rasmussen goes one step further than traditional hermeneutics.. In his words, he 'radicalizes' the hermeneutic method by treating both author and interpreter as autonomous observers operating each with their own distinctions, and thereby denying the possibility of a 'circular movement' (Rasmussen, 2002: 12) between observer and text, as was claimed by Gadamer. Texts are viewed as communication understood by an interpreter (Rasmussen, 2004: 341). By using his own distinctions, the interpreter observes the text's implicit and explicit distinctions as well as the selectivity and the blind spots of these distinctions (Rasmussen, 2004: 344). Depending on the research question and the theory the interpreter uses, he extracts certain information from a text by specifying the distinctions that are used in the text. The observed distinctions and their selectivity are to be found in the text. It only requires suitable theoretical tools to see them. ${ }^{3}$ Without - in our case - the Luhmannian theory of society we should not be able to observe what we observe when reading texts. 
III) Procedure of Radical Hermeneutics. The textual analysis is carried out in three consecutive steps (see Rasmussen, 2004: 344f). In the first step the texts in the sample are read in order to designate leading distinctions that will be used when interpreting the texts at later steps. Which leading distinctions can be applied depends on the concrete research questions of the interpreter. The complexity in a text can be reduced to those passages where the chosen leading distinction is explicitly or implicitly present. In the second step, these extracted text passages are interpreted on the basis of the distinctions used by the text (see next subsection). The purpose is to derive 'hypothetical constructions.' In the final step of the analysis, the sum of these distinctions will be interpreted (ibid: 344). Various texts can be compared with regard to differences and commonalities in how they observe and, as consequence, what descriptions are generated. Importantly, these comparisons are the product of the interpreter on the basis of hypothetical constructions (ibid: 348), and, we might add, on the basis of the systems-theoretical framework that guides the interpretations.

\subsection{Analysis and theoretical interpretation}

According to our pre-understanding as laid out in sections 2 and 3, potential candidates for priority criteria had to be reasonable exemptions from human dignity and equal human value. Therefore, the reading of the texts in step one aims at identifying and extracting passages in which the leading distinction 'reasonable exemption/human dignity principle' becomes relevant. Since this distinction itself is the result of our theoretical preparatory work, it is not necessarily directly visible in the text. When we analyse text passages that suggest a certain criterion, we treat 
the latter as operationalized distinctions; That is, the other side is not always uttered explicitly (or the author may not even be aware of it).

In the second step, we interpret those extracted statements and look for new distinctions used by the texts. As our study shows, only a few candidates gained resonance in the overall discussion since the early 1990s. Exemptions from 'human dignity' can be summarized by the principles 'medical need', 'solidarity (fairness)', 'cost-effectiveness' and 'responsibility for one's health'. ${ }^{4}$ These criteria are referred to in many texts on priority-setting and - with the exception of the responsibility principle - they have been included into the ethical platform from 1997. Medical need and solidarity are so far summarized in one principle; although there are suggestions to split them into two separate principles (Prioriteringscentrum, 2007).

The principles anchored in the platform claim to be ethical, and, as a result of our analysis in section 3, we can consider them as reasonable exemptions from the 'human dignity principle'. Each of these principles achieves this by establishing individual differences that justify exception from equality demands. In other words, each of these principles creates its own (legitimate) inequalities despite adhering to a general equality. Priority-setting due to medical needs focuses on individual bodies with individual disease patterns which by definition differ from others - even if the individual's right to treatment does not. Without challenging everyone's basically equal right to treatment, the cost-effectiveness principle establishes individual differences by calculating or estimating individual cost-outcome ratios on the basis of medical diagnoses. The solidarity principle tackles an individual's basic right to treatment with reference to the potentially jeopardized rights of others; by subordinating an individual's dignity to the dignity of a collective. We will now 
present two typical text passages from our data-body that criticize a one-sided

concentration on medical needs for the sake of solidarity.

In a situation of finite healthcare resources we have to get used to the thought that anything we offer for one patient unavoidably is taken from another. The desire of the infertile couple to have one or sometimes more children has to be weighed against a cancer-patient's need of terminal care. [...] Ethically it is not defendable to think simply about the need or the wishes of a patient we happen to have in front of us! (Björnståhl, 2004: 1835$)^{5}$

This excerpt utilizes the economic situation ('finite resources') as a boundary condition for a zero-sum game of allocation ('unavoidably'). Allocation is framed as an ethical matter because two distinct cases of medically possible (but optional) treatments have to be weighed on non-medical grounds. The reference-problem is that nobody should simply be privileged at the disadvantage of an abstract other. With currently valid moral values such a procedure would not be 'defendable'. Although the underlying ethical basis is the principle of human dignity/equality, the proposed solution - that is, solidarity - is the principle of priority-setting. The motto is something like: 'Don't waste scarce resources that other people might need more than you.' According to this excerpt, solidarity - although subordinate to human dignity - outranks medical needs.

From the viewpoint of medical ethics there is a conflict between the principle of doing good, i.e. to give every patient the best treatment possible, on the one hand, and the principle of fairness, i.e. that resources must be allocated with regard to other important needs within the group of patients as a whole, on the other hand. If the 'expensive' patients cost so much that other important needs of medical care cannot be satisfied, it might be reasonable to modify the principle of doing good. (Schöldström, 2008: 832)

From the explicitly ethical position this passage takes, it observes a trade-off between two moral principles ('doing good' versus 'fairness'). Given an economic boundary condition ('resources', 'expensive', 'cost'), doing 'good' is not always fair 
and vice versa. But the morally-evaluative perspective draws attention away from another distinction which is implied in the text and which indicates a deeper-lying structural conflict. The expensive 'best treatment possible' is only reasonable in a medical logic, whereas the logic of 'not jeopardizing other's medical needs because of single expensive treatment' refers to a politics of solidarity (see Hagen, 2000: 28). The structural conflict then lies in the irreconcilability of medical needs with solidarity. The solution suggested subordinates medical needs to solidarity. Put differently, the individual medical need appears less important than collective solidarity when resources are not sufficient for everyone.

As we suggest, the criteria proposed in the Swedish debate on prioritization can be sorted into two major groups according to whether their focus is on ill/injured human bodies needing treatment or on a collectivity that has to pay or dispense. Either priority should be set according to medical necessity/urge or along values of the welfare state, such as solidarity, fairness and cost-effectiveness. ${ }^{7}$ In other words, it is either medical rationality or welfare-political rationality that sets the frame for priority principles. These two lines of argument can be generalized into the distinction medical rationality/political rationality. This distinction is our hypothetical construction (compare section 4.1), i.e. it cannot necessarily be seen directly in the texts but is the result of interpreting them. Figure 3 shows this new distinction in terms of the new divider rationality, within the frame of reasonable exemptions of the HDP (within the frame of ethically acceptable criteria). 


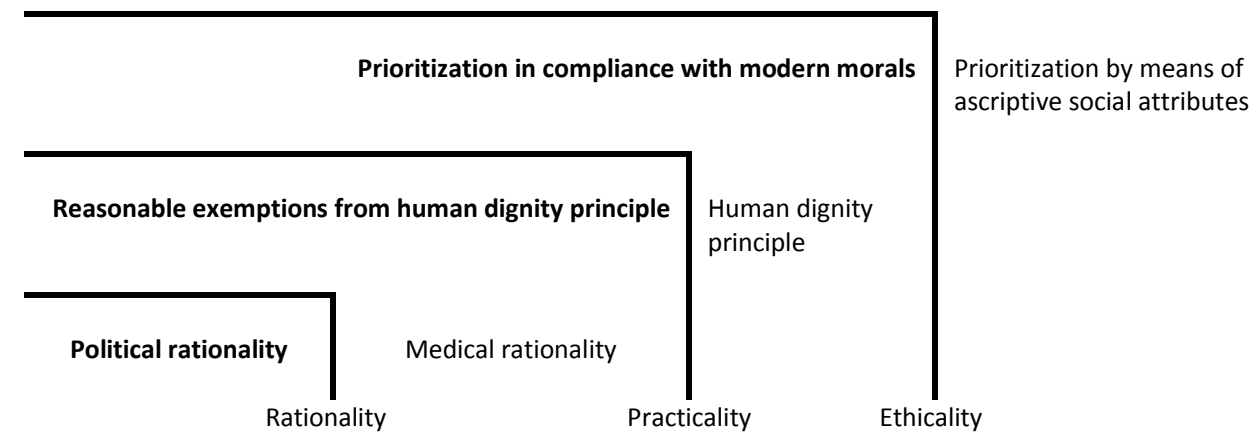

As the third step of our empirical investigation we compared the selected text passages in our sample with respect to the distinction between medical and political rationality. We looked for the lowest common denominator among the manifold arguments but could only detect another structural contradiction in the debate on priority-setting (next to the contradiction of prioritization among equals, see section 3). The aim of the third step of our analysis is therefore to find an adequate sociological interpretation of this structural incompatibility.

In line with Luhmann's theory of the functionally differentiated society (Luhmann, 1982; 1989; 1997), we interpret the two sets of relevance criteria as a mirror of the communicative logics of the two function systems of medicine and politics (Luhmann, 1990, 2000, 2005[1990]). Function systems (besides medicine and politics there are also the economy, religion, science, law, etc.) are complex communication systems that have developed a specific observational perspective and have evolved in reference to a specific societal reference-problem. The reference-problem of medicine is the functionality of the (ill) human body ${ }^{8}$. Medical communication centres on diseases, organisms, treatments and healing. In contrast, the reference problem of politics is a collectivity (Nassehi, 2002). It centres on binding decisions and power (Luhmann, 2000). If the political system describes itself 
as a welfare state (Luhmann, 1990) - as is the case in Sweden - binding decisions and power depend on legitimacy and collective support. Therefore, the state is keen on satisfying moral needs such as equality, solidarity, fair allocation of taxes and provision of services (security, education, infrastructure, or healthcare).

After sorting the analyzed arguments by the distinction 'medical relevance/welfare-political relevance' we can locate the structural problem that hampered decision-making in the operational difference of the two function systems of medicine and politics. Because both the observational perspectives and the reference-problems of medicine and politics are incongruent, medical and welfarepolitical criteria cannot outrank each other. Medical needs are not per se more important than solidarity and vice versa. In contrast to stratified societies of the past, modern society lacks a centre and a top. In other words, it lacks an 'Archimedean' standpoint that can objectively determine which criterion is more important or less. Medical needs appear more important than solidarity only when observed from the (self-referential) perspective of medicine but solidarity is more important only when seen from a (self-referential) welfare-political perspective. Medical and political logics are caught in their own self-reference. The functional differentiation of society does not allow an escape from these self-referentialities and their coequality. This incompatibility frames not only the debates on acceptance/rejection of rules but also available rule catalogues. In practical decision-making, physicians are forced to play the role of a doctor and a politician simultaneously (see Butler, 1999). ${ }^{9}$ 


\section{Scrutinizing the responsibility principle}

Policy-makers, physicians and healthcare economists share the impression that the ethical platform from 1997 failed to provide decision-makers on all levels with efficient guidelines for how to prioritize. The National Board of Health has sought a revision of the existing platform; it commissioned Prioriteringscentrum to analyse the problems in the existing platform and to make proposals for changes, amendments and clarifications. The report by Prioriteringscentrum (Prioriteringscentrum, 2007: 47) suggested reactivating the 'responsibility principle' that was already considered but rejected by an official government report in 1993 (SOU, 1993). According to this principle, patients are held responsible for their illness if they conduct an unhealthy lifestyle (e.g. wrong diet, physical inactivity, abuse of narcotics) and those who fail to live up to these expectations can legitimately be given lower priority (Michailakis and Schirmer, 2010). After Prioriteringscentrum's report, several other articles and documents supported the idea of individual responsibility for one's health (see Socialstyrelsen, 2007: 13; Furberg, 2007; Ohlin, 2008).

Can the responsibility principle bridge the divide between medical and welfare-political logics as mirrored in the jamming conflict between the principles of medical need and solidarity? We revisited our text material and selected only those texts with the keywords 'responsibility' and 'lifestyle,' and analysed explicit and implicit distinctions in the texts that discussed the responsibility principle as a criterion for priority-setting. Let us take a closer look at a short passage from the report by Prioriteringscentrum from 2007 which promoted the principle. 
Responsibility for one's health denotes the obligation to preserve or improve one's health. The obligation can be fulfilled by preventing illness. For example, this can be done by choosing a healthy lifestyle or by avoiding unnecessary health risks. [...] The obligation to improve one's health can comprise obedience to the instructions by the healthcare personnel or providing necessary self-care. (Prioriteringscentrum, 2007: 135f)

Unequivocally, the excerpt links responsibility to one's health with lifestyle, an unhealthy lifestyle indicating irresponsibility because it brings about unnecessary hazards for an individual's health condition and, thereby, violates an individual's obligation to take care of his health. Somewhat hidden, yet present in this text, the moment of choice is ascribed to the individual: the choice to take care of or (continuing) to endanger one's health.

The text material suggests that 'responsibility for one's health' and '(un)healthy lifestyle' are often closely interconnected without clear delimitation. However, this connection has to be treated with care because they refer to logically different and incompatible causal chains. The first chain can be seen in the following text passage from a report by the Swedish National Institute of Public Health to encourage physical activity:

Both the increasing emergence of cancer and the rising share of the population who lives with the disease are linked to our sedentary lifestyle. A growing amount of studies shows that there is a link between physical inactivity and a number of cancer forms; and it is discussed whether physical inactivity can also have an impact on treatment and rehabilitation. (Statens Folkhälsoinstitut, 2008: 344)

By using the example of physical motion, this excerpt points out a causal relation between people's lifestyle and their health condition. This connection is detected and increasingly established by scientific research. Since the effects of lifestyle on disease can be measured and verified by data (and falsified by new data), it can be treated as an objective fact and allows hypothesis-like statements such as 'physical inactivity makes cancer likely.' 
Responsibility for one's health, by contrast, assumes that this chain of events is (more or less) mediated by the intentional actions of an individual; For instance as expressed by the statement, 'being not physically active, it is your fault if you become ill with cancer.' It presupposes agency, that is, the choice to act differently. Holding somebody responsible for something he could not avoid would not constitute a legitimate basis. However, the extent of this choice cannot be measured objectively but has to be attributed by observers (Luhmann, 1995: chap. 4; Fuchs, 2001). Despite the (measurable) effect of physical inactivity on disease, it is another question - with totally different implications - to ask whether the patient is not physically active because he does not want to be, because he does not know about the consequences of his inactivity, because he is impaired or because the social milieu he lives in does not encourage motion. Accordingly, critics remark that attributions of responsibility are generally arbitrary and therefore unsuitable for priority-setting (see SOU, 1993; The Swedish Government, 1997; Minkler, 1999; Wikler, 2002; Sahlin, 2008, Hermerén, 2009).

While we refrain from downplaying these difficulties with the responsibility principle, we consider the incongruity of the two causal logics of lifestyle and responsibility a more severe problem; especially because the parties involved in the debate believe that they are referring to the same thing while actually they do not. In order to avoid that mistake, we must keep apart a number of distinctions (see figure 4). Representing separate logics, '(un)healthy lifestyle' and 'responsibility for one's health' each belong to different distinctions with different antonyms (counterconcepts). Lifestyle in the context of health acquires its meaning in contrast to genetic inheritance. Both are united in this one distinction because they are seen as 
possible causes/facilitators of disease and have definite (positive or negative) effects on therapies, respectively (Glannon, 1998). The causal relations are treated as objective facts, established by methodologically controlled observation. What divides the two sides of the distinction is the extent to which the cause of disease is amenable to influence. Whereas hereditary predispositions are considered fixed (at least up to now), lifestyle can be adjusted. In contrast, responsibility is a matter of attributing agency, and the dividing question is: can the individual be seen as an agent? That is, does he have a choice to act differently, and thereby may be held responsible, or is he just a victim of circumstances beyond his control, and thereby may seen as non-responsible?

Lifestyle and responsibility are not only two different things; they also refer to different function systems, and not surprisingly these are the two systems medicine and politics. The distinction lifestyle/genetic inheritance is genuinely medical because it aims at the reference-problem of medicine, i.e., analysing causes for and cures of diseases. Seen from this perspective, prioritization follows the most urgent needs and highest likelihoods of successful treatment.

Politics has no competence to determine the consequences of lifestyle on health (Svenska Läkaresällskapet, 2004: 5). From a political perspective, prioritization is a matter of fair allocation of scarce resources. The reference-problem of the welfare state is to achieve collective legitimacy for its (not always popular) binding decisions, like down-prioritizing some people despite the rule of every individual's equal value (Schirmer and Michailakis, 2012). By attributing agency to these people, the state can implement such measures in the name of ethicality. Against this background, the distinction responsibility/non-responsibility is political - not 
medical. Figure 4 visualizes the continuation of the Spencer-Brownian 'forms' on a yet more inclusive level. Both concepts of responsibility for one's health and (un)healthy lifestyle become relevant in terms of reasonable exemptions of the HDP, and thereby are ethically acceptable options. However, they are meaningful only in their own sphere of rationality, and accordingly, belong to different distinctions.

Figure 4: Attribution of agency and cause of disease'

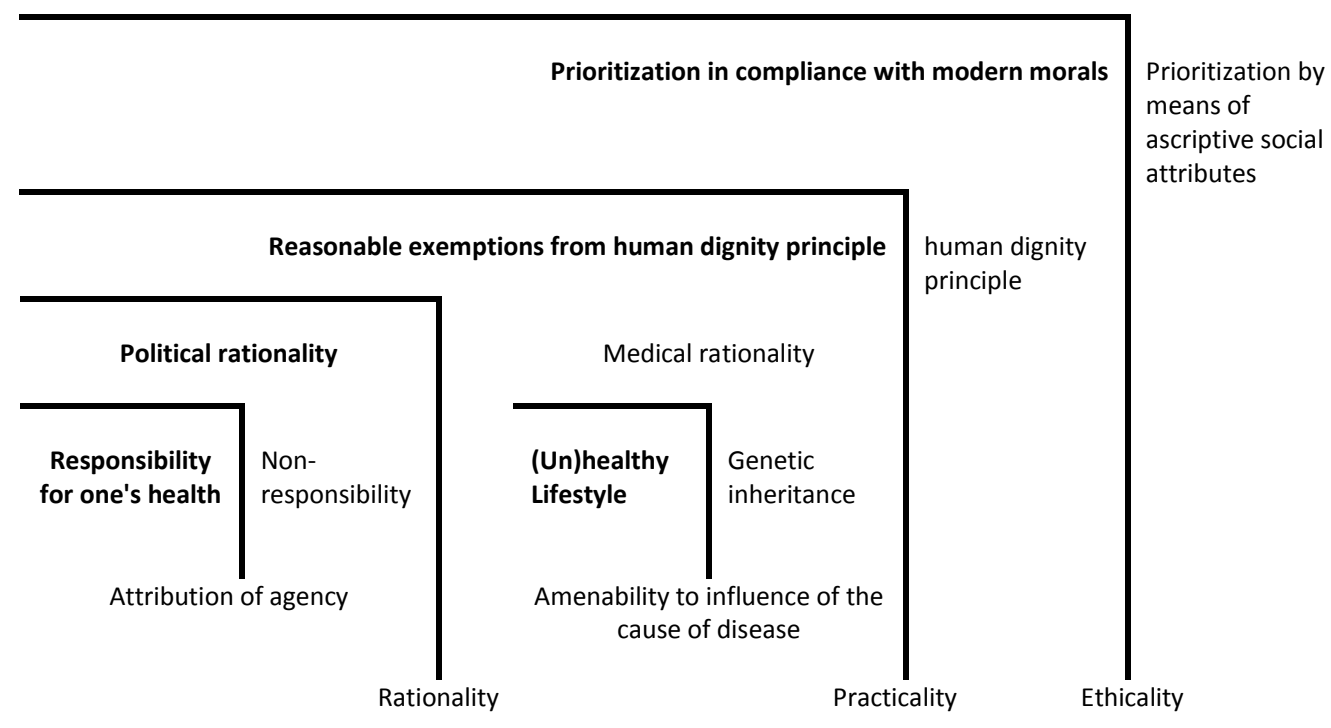

The peculiarity here, however, is the detour via the medical system the welfare state takes. As pointed out in section 3, the human dignity principle does not allow down-prioritizing on illegitimate grounds. Since a blunt 'blame the victim'policy would rather lead to discontent than allegiance, a more elegant way to solve the political puzzle has to be found. So, largely unnoticed, perhaps even unintended, the state instrumentalizes medically established facts (such as the causal relation between lifestyle and health outcome) in order to find legitimate exemptions from human equality without contradicting its self-description of being a caring welfare state (Luhmann, 1990; Nassehi, 2002; Schirmer and Michailakis, 2012). Those who 
fail to live up to the expectations of a healthy lifestyle can be legitimately excluded from benefits. This procedure pretends to be a medical selection, but it is not. In a medical context, individuals are relevant as bodies but not as agents. Consequently, the medical system can establish facts but has no conception of responsibility. The moment of choice that enables the attribution of responsibility in the causal relation (lifestyle $\Rightarrow$ health outcome) is added by the political system.

\begin{abstract}
The principle of individual responsibility is based partly in the human dignity principle and partly in the idea of solidarity between people. The former means [...] that we should regard people as responsible for their actions and the consequences of their actions - e.g., their health. The idea of solidarity demands a general awareness of public resources. The person who wastes public funds exposes others to difficulties when the resources are not sufficient. (Prioriteringscentrum, 2007: 134)
\end{abstract}

This excerpt from Prioriteringscentrum's report presents an individual's unhealthy lifestyle as an avoidable waste of scarce resources that the collective (i.e. other people) has to pay for. In this light, an unhealthy lifestyle is in conflict with solidarity towards the collective. Therefore, people are not only held responsible for their health for their own sake but because they charge public budget that could be used for other people instead. This argument establishes a logical connection between responsibility and solidarity. More concretely, we can now interpret the responsibility principle as a special case of the solidarity principle. The responsibility principle, unmasked as a political device, contradicts the principle of medical need. While medical needs exist independently from whether the disease is inflicted by the patient herself or by other factors, responsibility is attributed according to political values, and therefore (logically) independently from medical diagnoses. The practical consequence is that the responsibility principle cannot contribute to better, more effective directives for decision-making. Quite the reverse, it amplifies the conflict observed earlier. Physicians are hampered in the execution of their actual profession 
to treat people according to their medical needs. Instead of being disburdened by clear directives, they are rather exploited as henchmen of the welfare state, now even having to judge the extent of people's agency in complex situations.

\section{Conclusion}

The modern values of human dignity and equal value are too important to be ignored in delicate matters such as healthcare prioritization. Due to the inherent paradox of prioritizing among people with equal worth, the human dignity principle cannot provide guidelines for decision-making. The latter becomes yet more complicated when ethical criteria have to be formulated in the name of, and not against, this principle. To dissolve the contradiction, reasonable exemptions from human dignity have to be found. Such criteria, e.g. medical needs or costeffectiveness, are hardly combinable. Rather, they can be contested by one another without any of them being more true or reasonable than the other. We find that this deadlock is to a certain extent due to the poly-contextural macro-structure of modern society. Characterized by difference instead of unity, society lacks a central meta-position from which universally valid observations could be made. Instead, there is a multitude of co-equal function-system specific perspectives, each of which provides its own description of truth and follows its own rationality. Politics is just one among them; medicine is another one of equal rank and, therefore, none is in a position to dictate to the other its own conditions. The proposed criteria follow either medical or welfare-political rationality, and none is per se more rational. ${ }^{10}$

Our analysis shows that the deadlock cannot be overcome by introducing a principle based on individual responsibility for one's health. The connection between responsibility and lifestyle falsely assumes a subordination of medicine to politics. 
While responsibility is a political notion building on the contingent attribution of agency due to current political interests, there is no corresponding concept in medicine. (Un)healthy lifestyle assumes causal reasoning about objectively measureable facts and cannot simply be usurped by political logics.

The aim of this article was not to provide a solution to the moral dilemmas of priority-setting. With our analysis, we can however point out the direction that the search for solutions should take or, rather, should not take. We feel that the lack of an adequate sociological theory increases the risk of making similar mistakes as were made in the ethical platform from 1993/1995. At that time, it was the coupling of needs and solidarity; now it is the combination of lifestyle and responsibility. Our intension is not to spread pessimism, but we want to point out that viable solutions to the described dilemmas cannot be reached if policy-makers continue to ignore society's functional differentiation. Medicine and politics are each autonomous spheres, and therefore it is impossible to integrate their rationalities. Any solution must be in line with - not against - functional differentiation. Politics can deal with political problems, and it might be more successful when it respects medical autonomy instead of trying to integrate medicine and politics.

\section{References}

Aftonbladet (2009) Att köpa sig ett längre liv [Buying a longer life]. [Article without author] 15 May.

Beck-Gernsheim E (2000) Health and Responsibility: From Social Change to Technological Change and Vice Versa. In Adam B, Beck $U$ and van Loon J (eds) The Risk Society and Beyond. Critical Issues for Social Theory. London: Sage, 122-135.

Brodén S (2008) Kvinnor får sämre vård [Women receive worse care]. Dagens Nyheter 30 September.

Björnståhl H (2004) Det är läkarnas ansvar att rätta mun efter matsäck! [It's the 
doctors' responsibility to cut their coats according to their cloths!]. Läkartidningen 101(20): 1834-1835.

Butler J (1999) The Modern Doctor's Dilemma: Rationing and Ethics in Healthcare. Journal of the Royal Society of Medicine 92(8): 416-421.

Callahan D (1987) Setting Limits. Medical Goals in the Aging Society. New York: Simon \& Schuster.

Calltorp J (1989) Prioritering och Beslutsprocess i Sjukvårdsfrågor [Prioritization and Decision process in healthcare issues]. Unpublished doctoral thesis. Uppsala University, Department of Social Medicine, Uppsala.

Calltorp J (1992) Prioritering en del av sjukvårdens framtid: De oundvikliga valen [Prioritization is a part for the future of healthcare: The inevitable choices]. Nordic Journal of Psychiatry 46(3): 145-148.

Calltorp J (1999) Priority setting in health policy in Sweden and a comparison with Norway. Health Policy 50(1): 1-22.

Daniels N and Sabin JE (2002). Setting Limits Fairly: Can We Learn to Share Medical Resources? Oxford: Oxford University Press.

Donahue MJ and McGuire BM (1995) The Political Economy of Responsibility in Health and IIIness. Social Science and Medicine 40(1): 47-53.

Esping-Andersen G (1990) The Three Worlds of Welfare Capitalism. Princeton: Princeton University Press.

Fuchs S (2001) Beyond Agency. Sociological Theory 19(1): 24-40.

Furberg, E (2007) Ansvar för sin hälsa? Problem och möjligheter med att tillämpa en ansvarsprincip inom hälso- och sjukvården [Responsibility for one's health? Problems and opportunities of applying a responsibility principle in healthcare]. Linköping: Prioriteringscentrum.

Ginzberg E (1990) The medical Triangle - Physicians, Politicians and the Public. Cambridge: Harvard University Press.

Glannon W (1998) Responsibility, Alcoholism, and Liver Transplantation. Journal of Medicine and Philosophy 23(1): 31-49.

Gunnarsdotter S (2007) Primärvården saknar öppna och tydliga prioriteringar [Primary healthcare lacks open and clear prioritizations]. Läkartidningen 104(43): 3172-3174.

Hagen R (2000) Rational Solidarity and Functional Differentiation. Acta Sociologica 43(1): 27-42.

Ham C (1997) Priority setting in health care: learning from international experience. Health Policy 42(1): 49-66.

Ham C and Glen R (eds) (2003) Reasonable Rationing. International Experience of Priority Setting in Health Care. Berkshire: Open University Press.

Hermerén G (2009) Redskap finns och plattformen håller - men kunskapsunderlaget är bräckligt för prioriteringar i vården [Equipment is there and the platform is tight - but the knowledge is fragile for healthcare prioritizations]. Läkartidningen. 106(42): 2702-2703.

Jolanki O (2008) Discussing responsibility and ways of influencing health. International Journal of Aging and Later Life 3(1): 45-76.

Light DW and Hughes D (2001) Introduction: A sociological perspective on rationing: power, rhetoric and situated practices. Sociology of Health and IIIness 23(5): 551-569. 
Luhmann N (1982) The Differentiation of Society. New York: Columbia University Press.

Luhmann N (1989) Ecological Communication. Chicago: University of Chicago Press.

Luhmann N (1990) Political Theory in the Welfare State. Berlin: Walter de Gruyter.

Luhmann N (1995) Social Systems. Palo Alto: Stanford University Press.

Luhmann N (1997) Die Gesellschaft der Gesellschaft. Frankfurt/Main: Suhrkamp.

Luhmann N (2000) Die Politik der Gesellschaft. Frankfurt/Main: Suhrkamp.

Luhmann N (2005 [1990]) Der medizinische Code. In Luhmann N (ed.) Soziologische Aufklärung 5. Konstruktivistische Perspektiven. Wiesbaden: VS Verlag, 176188.

Luhmann N (2006) System as Difference. Organization 13(1): 37-57.

Martin DK, Giacomini M and Singer PA (2002) Fairness, accountability for reasonableness, and the views of priority setting decision-makers. Health Policy 61(3): 279-290.

Michaelis AP (2002) Priority-Setting Ethics in Public Health. Journal of Public Health Policy 23(4): 399-412.

Michailakis D and Schirmer W (2010) Agents of their health? How the Swedish Welfare State Introduces Expectations of Individual Responsibility. Sociology of Health and IIIness 32 (6): 930-947.

Minkler M (1999) Personal Responsibility for Health? A Review of the Arguments and the Evidence at Century's End. Health Education and Behavior 26(1): 121-141.

Nassehi A (2002) Politik des Staates oder Politik der Gesellschaft? Kollektivität als Problemformel des Politischen. In Hellmann K-U and Schmalz-Bruns R (eds) Theorie der Politik. Niklas Luhmanns politische Soziologie. Frankfurt/Main: Suhrkamp, 38-59.

Ohlin E (2008) 'Svart lista' politiskt tabu ['Black list' political taboo]. Läkartidningen 105(16): 1160-1162.

Olsen JA (1997) Theories of justice and their implications for priority setting in health care. Journal of Health Economics 16(6): 625-639.

Prioriteringscentrum (2007) Vårdens alltför svåra val? Kartläggning av prioriteringsarbete och analys av riksdagens principer och riktlinjer för prioriteringar i hälso- och sjukvården. [Resolving Health Care's Difficult Choices. Survey of Priority Setting in Sweden and an Analysis of Principles and Guidelines on Priorities in Health Care] Linköping. Available at: http://www.imh.liu.se/halso-ochsjukvardsanalys/prioriteringscentrum/publikationer/prioriteringscentrumsrapportserie-2004-2006/1.192878/2007.2.pdf

Rasmussen J (2002) Textual Interpretation and Complexity - Radical Hermeneutics. Paper presented at The American Educational Research Conference. New Orleans.

Rasmussen J (2004) Undervisning i det refleksivt moderne. Copenhagen: Hans Reitzels Forlag.

Riksrevisionen (2004) Riktlinjer för prioriteringar inom hälso- och sjukvård [Directives for healthcare prioritizations]. RiR. 2004:9. Stockholm.

Sahlin N-E (2008) Kritik mot Prioriteringscentrums förslag till ny prioriteringsplattform: Från allas lika värde till hälsoekonomisk kalkyl 
[Critique against Prioriteringscentrum's proposal for new prioritiation platform: From everybody's equal value to health-economic calculation]. Läkartidningen 105(37): 2465-2466.

Schirmer, W and Michailakis D (2012) The latent function of 'responsibility for one's health' in Swedish healthcare priority-setting. Health Sociology Review 21(1): 36-46.

Schöldström U (2008) Prioriteringarna i vården - vad får etiken kosta? [Prioritizations in healthcare - how much may ethics cost?]. Läkartidningen 105(11): 831-832.

Seidl D and Becker K-H (2006) Organizations as Distinction Generating and Processing Systems: Niklas Luhmann's Contribution to Organization Studies. Organization 13(1): 9-35.

Socialstyrelsen [The National Board of Health and Welfare] (2007) Prioriteringar $i$ hälso- och sjukvården. Socialstyrelsens analys och slutsatser utifrån rapporten 'Vårdens alltför svåra val?'. [Prioritizations in healthcare. The National Board's analysis and conclusions from the report 'Resolving Health Care's Difficult Choices'] Stockholm.

SOU [Statens offentliga utredningar/Governmental official reports] (1993). Vårdens svåra val. Rapport från utredningen om prioriteringar inom hälso- och sjukvården. [The difficult choices of healthcare. Report from the investigation on prioritizations in healthcare] SOU 1993:93. Stockholm: Allmänna förlaget.

SOU [Statens offentliga utredningar/Governmental official reports] (1995). Vårdens svåra val. Slutbetänkande från prioriteringsutredningen. [The difficult choices of healthcare. Final decisions from the investigation on prioritizations] SOU 1995:5. Stockholm: Fritzes offentliga publikationer.

SOU [Statens offentliga utredningar/Governmental official reports] (2001). Prioriteringar $i$ vården - Perspektiv för politiker, profession och medborgare. [Prioritizations in healthcare - perspectives for politicians, profession and citizens] SOU 2001:8. Stockholm: Fritzes offentliga publikationer.

Spencer-Brown G (1994) Laws of Form. Portland: Cognizer Co.

Statens Folkhälsoinstitut (2008) Fysisk aktivitet $i$ sjukdomsprevention och sjukdomsbehandling [Physical activity in prevention and treatment of illness]. Stockholm. Available at:

http://www.vgregion.se/Pages/89295/fyssen.pdf

Stichweh R (2000) Systems Theory as an Alternative to Action Theory? The Rise of 'Communication' as a Theoretical Option. Acta Sociologica 43(1): 5-13.

Svenska Läkaresällskapet [Swedish Society of Medicine] (2004) Öppna prioriteringar av hälso- och sjukvård. Slutrapport från Svenska Läkaresällskapets prioriteringskommitté [Open healthcare prioritizations. Final report from the prioritization committee of the SwedishSociety of Medicine]. Available at:

http://www.svls.se/cs-media-old/xyz/000003156.pdf

The Swedish Parliament. Regeringsformen. Chapter 1.

The Swedish Government (1997). Proposition [Government Bill] 1996/97:60. Prioriteringar inom hälso- och sjukvården [Prioritizations in healthcare]. Stockholm.

The Swedish Government (2008). Proposition [Government Bill] 2007/08: 110. En förnyad folkhälsopolitik [A renewed public health policy]. Stockholm. 
Turner B (2004) The New Medical Sociology: Social Forms of Health and IIIness. New York: Norton.

Vanderstraeten R (2001) Observing Systems: a Cybernetic Perspective on System/Environment Relations. Journal for the Theory of Social Behaviour 31(3): 297-311.

Wikler, D (2002) Personal and Social Responsibility for Health. Ethics \& International Affairs 16(2): 47-55.

\section{Notes}

${ }^{1}$ This theoretical ceteris paribus case differs from 'real' prioritizations insofar as those often deal with different illnesses which are difficult to compare.

${ }^{2}$ This and the following translations from Swedish are our own.

${ }^{3}$ The found information is likely to differ from that of other interpreters (who use other theoretical tools and therefore emphasize other distinctions). When using a Foucauldian perspective, the analyst might find other things in the text than when using a psychoanalytical or a Luhmannian perspective. The applied perspective - in other words, the particular observer's scheme of observation - then, is a pivotal factor for the findings; not the text alone. Nevertheless, the observer does not 'make things up' independent from the interpreted text. Information is in the text, and, therefore, can be extracted.

${ }^{4}$ The responsibility principle has been present from the beginning of the Swedish priority debates (see SOU, 1993: 103f) but only gained significance in the last few years. It will be discussed extensively in section 5.

${ }^{5}$ This passage is taken from a debate article by a surgeon general arguing that doctors need to take responsibility to save resources by avoiding unnecessary treatments.

${ }^{6}$ This passage is taken from an article by the former chief investigator of the Swedish Medical Association. It summarizes a report by the association's Council for Ethics and Responsibility according to which claims to prioritization have to be made rather by doctors in clinics than by politicians.

${ }^{7}$ Note that 'cost effectiveness' is neither an economic nor a medical but a welfare-political principle. The question whether the implantation of an expensive artificial hip or a cheaper but less functional solution 'pays off better' when the patient is 85 years cannot be answered in economic or medical terms but only in terms of moral values the welfare state adheres to. Scarcity of financial resources in health care is a matter of the welfare state's budget and refers to distributive fairness instead of profitability of investments (that are characteristic for economic operation modes).

${ }^{8}$ When we speak of body here, we include mental systems to the extent they become object of diagnoses and treatment in psychiatry.

${ }^{9}$ It is telling that the ethical platform from 1993/1995 packed together the criteria 'medical need' and 'solidarity' under the same rule ('Behovs- och solidaritetsprincip'). According to our analysis, this measure made invisible an inherent contradiction with outcomes similar to the contradiction of prioritizing among equals pointed out in section 3. More recently, this mistake was detected and a split into two different principles was recommended (Prioriteringscentrum, 2007: 119), but even the dispersion cannot make congruent two criteria that derive from two incongruent function systems.

${ }^{10}$ Sure enough, in a stratified society with top and centre, the conflict between moral principles, e.g. between human dignity and medical need would still prevail. The important argument is, however, that in such a society some principles could be given more weight (by authority, or by leading and unquestionable ideologies), and conflicting principles could be banned, subordinated or even ignored. We thank one of the anonymous referees for pointing this out. 